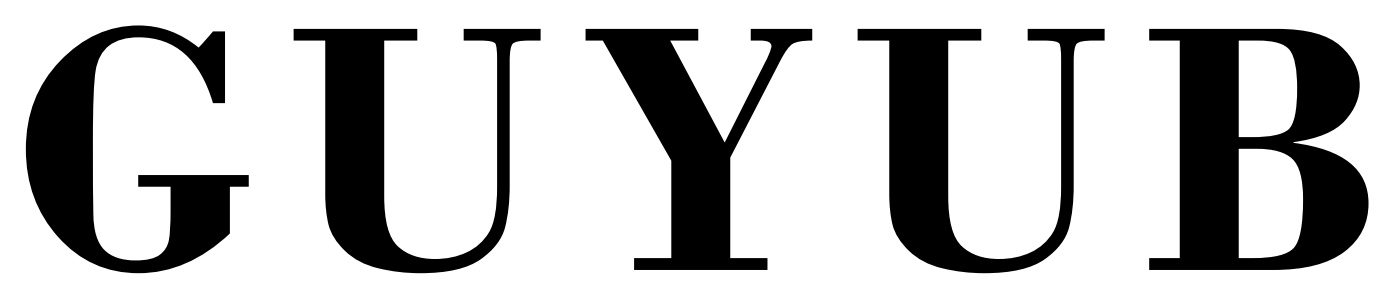

Journal of Community Engagement

Vol. 2, No. 2, Agustus 2021

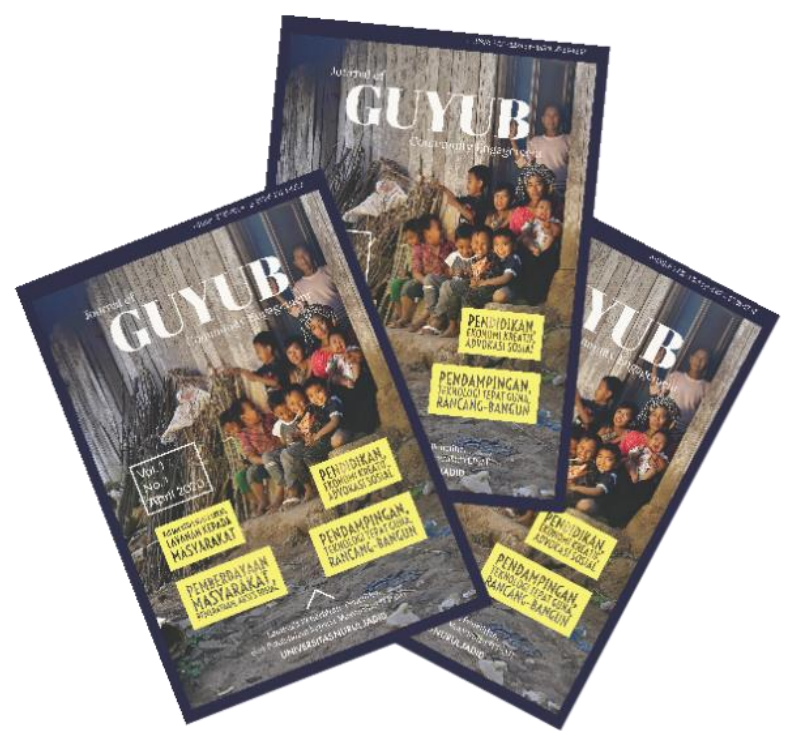

PKM Pendampingan Santri Nurul Jadid melalui Gerakan Literasi Cerdas dalam Membentuk Komunitas Pelajar Berkarakter Islam di Pondok Pesantren Nurul Jadid

Faizatul Widat, Afita Khoirun Nisa', Wardatul Habibah, Wahibatul Mas'ula, Nikmatul Hosniah, Jamilatul Masnunah, Hamidah

PKM Penyuluhan Pembuatan dan Penyemprotan Disinfektan (PEPEDES) sebagai Upaya Pencegahan Covid-19 di Desa Kalikajar Kulon Probolinggo

Fahrudin, Ayu Midyah Putri, Abdul Hamid Isnaini, Abdul Latif Isnaini, Duwi Handika Okta Rotama, Rosi Nurjannah, Suharno

PKM Pendampingan Penyusunan Kurikulum Sekolah Ramah Anak pada Taman Kanak Kanak (TK) Az-Zainiyah II Paiton Probolinggo

Abu Hasan Agus R, Durratul Mashunah, Hostin, Hilyah Mashunah, Siti Rahayu, Atik Hikmatuz Zakiyah 


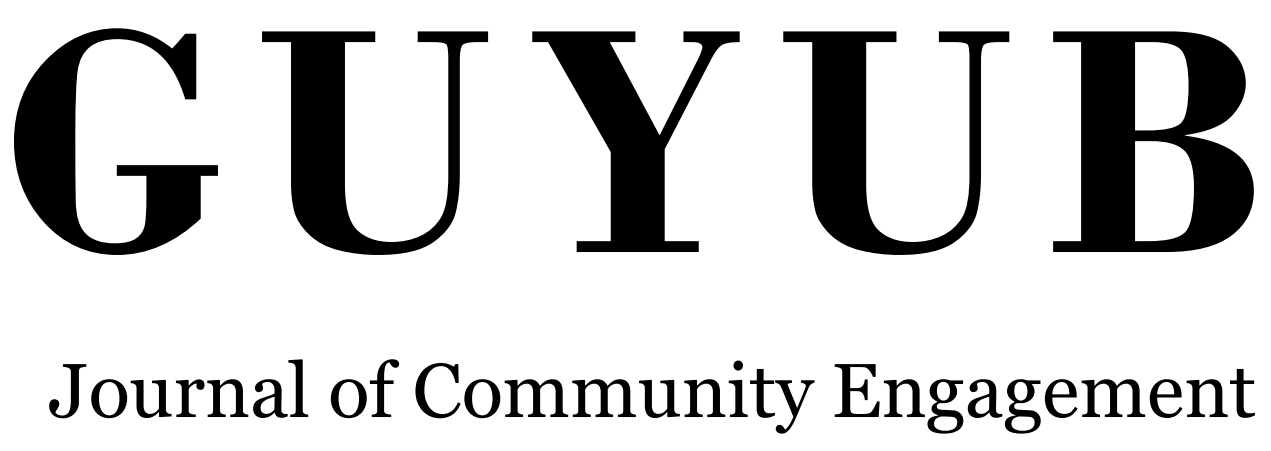




\section{G U Y U B}

\section{Journal of Community Engagement}

Vol. 2, No. 2, 2021

\section{Editor in Chief}

Achmad Fawaid, (SCOPUS ID: 57214837323)

\section{Managing Editors}

Hasan Baharun, (ID SCOPUS : 57200983602)

Sugiono Sugiono, (SCOPUS ID : 57199578160)

Ismail Marzuki, (SCOPUS ID: 57201500245

Subhan Rachman, (SCOPUS ID: 57192937912)

Nurul Huda, (SINTA ID: 6119615)

Syamsuri, (SINTA ID: 6116825)

Ridhatullah Assya'bani, (SINTA ID: 6200862)

\section{Peer Reviewers}

Miftahul Huda, (SINTA ID: 6171566), University of Antwerp, Belgium Achmad Naufal Irsyadi (SINTA ID: 6704870), Universitas Nurul Jadid, Indonesia Sukamto Sukamto, (SINTA ID: 5979034), Universitas Widya Gama Malang, Indonesia Deny Utomo, (SINTA ID: 6016108), Universitas Yudharta Pasuruan, Indonesia Fariz Alnizar, (SCOPUS ID: 6659824), UNUSIA Jakarta, Indonesia Fuad Rahman, (SCOPUS ID: 57201474778), UIN Sulthan Thaha Saifuddin Jambi, Indonesia Saifuddin Zuhri Qudsy, (SCOPUS ID: 57213595165), UIN Sunan Kalijaga Yogyakarta, Indonesia Akhmad Anwar Dani, (SINTA ID: 14305), IAIN Surakarta, Indonesia Maufur Maufur, (SINTA ID: 5989329), IAIN Kediri, Indonesia Siti Mahmudah Noorhayati, (SINTA ID: 6726997), IAIN La Roiba Bogor, Indonesia Busro Busro, (SCOPUS ID: 57205022652), UIN Sunan Gunung Djati Bandung, Indonesia Akmal Mundiri, (SCOPUS ID: 57205059378), UNUJA Probolinggo, Indonesia

\section{Section Editor}

Ahmad Zubaidi, Universitas Nurul Jadid, Probolinggo, Indonesia 
GUYUB: Journal of Community Engagement is a multidisciplinary journal which aims to disseminate the conceptual thoughts and research results in the area of community service. This journal focuses on the main problems of the community engagement areas, such as (1) training, marketing, appropriate technology, design; (2) student community services; (3) community empowerment, social access; (4) education for sustainable development, etc.

GUYUB: Journal of Community Engagement is published three times a year (April, August, December) by Lembaga Penerbitan, Penelitian, dan Pengabdian kepada Masyarakat (LP3M) Universitas Nurul Jadid, Paiton, Probolinggo, Jawa Timur, Indonesia.

Editorial Office:

GUYUB: Journal of Community Engagement

Lembaga Penerbitan, Penelitian, dan Pengabdian kepada Masyarakat (LP3M) Universitas Nurul Jadid, Paiton, Probolinggo, Jawa Timur, Indonesia 67291.

Phone: 088830 77077, Hp: 082318007953

Email: jurnal.guyub@gmail.com

Website: https://ejournal.unuja.ac.id/index.php/guyub/index 


\section{Tables of Content}

178-191

PKM Pendampingan Santri Nurul Jadid melalui Gerakan Literasi Cerdas dalam Membentuk Komunitas Pelajar Berkarakter Islam di Pondok Pesantren Nurul Jadid

Faizatul Widat, Afita Khoirun Nisa', Wardatul Habibah, Wahibatul Mas'ula, Nikmatul Hosniah, Jamilatul Masnunah, Hamidah

192-201

PKM Pelatihan Deep-Listening untuk Meningkatkan Kemampuan Berbahasa Inggris Santri Nurul Jadid Durratul Hikmah, Taufiqur Rahman, Irfan Wahyudi, Nur Hayati, Ahmad Zainullah, Kuni Zakiya Maskuroh

$202-210$

PKM Pendampingan Speaking Skill dengan Metode TROPIG di Wilayah Al Hasyimiyah Pondok Pesantren Nurul Jadid

Syaiful Islam, Nur Azizah, Rifdatul Qomariyah, Anis Fitria, Nurul Hamidah, Masrufah Masrufah

\section{1-224}

PKM Penyuluhan Pembuatan dan Penyemprotan Disinfektan (PEPEDES) sebagai Upaya Pencegahan Covid-19 di Desa Kalikajar Kulon Probolinggo

Fahrudin, Ayu Midyah Putri, Abdul Hamid Isnaini, Abdul Latif Isnaini, Duwi Handika Okta Rotama, Rosi Nurjannah, Suharno

225-232

PKM Pelatihan Pengisian Pengajuan Izin Operasional Taman Pendidikan Al-Quran secara Online Moh Jasri, Muhammad Romdloni, Mohammad Akmalor Riski, Nurul Hidayatullah, Muhammad Hasan Andika, Yogi Angga Praditya, Syukron Khafi, Shancen Ammabiel

\section{3-249}

PKM Pelatihan Pemanfaatan E-Learning Berbasis Teknologi Berbasis Platform Google Classroom bagi Guru Madrasah Ibtidaiyah Nurul Mun'im (MINM) Paiton Probolinggo

Feriska Listrianti, Nur Ika Sari, Siti Khomariya, Huswatun Hasanah, Millatun Hanifah, Deviyatul Hasanah

250-264

PKM Pelatihan Tutor Lembaga Kebahasaan Az-Zainiyah melalui Game Islami untuk Meningkatkan Keterampilan Berbicara Bahasa Inggris

Bradhiansyah Tri Suryanto, Nur Hasanah, Nuril Diar Anas, Sri Waliyul Hasanah, Syaiful Syaiful, Lia Umami

\section{5-275}

PKM Deteksi Dini Kelainan Tumbuh Kembang dengan Skrining Denver II dan Health Education di Taman Pendidikan Anak Shaleh Nurul Jadid Paiton Probolinggo

Zainal Munir, Zainul Hasan, Siti Nur Kholishoh, Melinia Akhirul Fitri 
PKM Habituasi Nilai-Nilai Keagamaan melalui Kegiatan Rohani DITABERHAMAN dalam Menciptakan Kesalehan Sosial di Pondok Mahasiswi (POMASI) Nurul Jadid Paiton Probolinggo

Zakiyah BZ, Ana Muthmainnah, Aminatuz Zuhriyah, Hamidah Hamidah, Miftahul Jannah, Wardatus Sholihah, Elok Nafiqoh

293-302

PKM Diversifikasi Ragam Produk Olahan Berbahan Dasar Ikan Teri sebagai Upaya Peningkatan Ekonomi Masyarakat Paiton Probolinggo

Saifuddin, Andre Dimas Fernando Putra, Moch Sofyan, Fadhlur Rohman, Mohammad Hasan Ainul Yaqin, Nailis Saadah Ali

303-312

PKM Pendampingan Penyusunan Kurikulum Sekolah Ramah Anak pada Taman Kanak Kanak (TK) AzZainiyah II Paiton Probolinggo

Abu Hasan Agus R, Durratul Mashunah, Hostin Hostin, Hilyah Mashunah, Siti Rahayu, Atik Hikmatuz Zakiyah

\section{3-325}

PKM Pelaksanaan Kegiatan Ekstrakurikuler Keagamaan dalam Membangun dan Mengembangkan Bakat dan Minat Santri pada Bidang Keagamaan di Madrasah Tsanawiyah (MTs) Nurul Jadid Probolinggo

Abdullah, Habibaturrohmah Habibaturrohmah, Halimatus Sakdiyah, Aisyah Amini, Putri Yunita Sari, Lilis Sulistiawati, Fitriyatun

326-341

PKM Sosialisasi Aplikasi Edmodo sebagai Alternatif Media Pembelajaran Daring di Madrasah Ibtidaiyah (MI) Az-Zainiyah II Paiton Probolinggo

Niken Septantiningtyas, Suhairiyah Suhairiyah, Fadilatul Hasanah, Umatuz Sholihah

$342-350$

PKM Pendampingan Pelatihan Penulisan Karya Tulis IImiah dalam Meningkatkan Kompetensi Guru di Madrasah Tsanawiyah (MTs) Nurul Jadid Paiton Probolinggo

Musolli Ready, Moh. Amir Kholili, Moh. Abd Mu'iz, Jefri Jefri, Moh. Agus, Moh. Ridwan Kamil

$351-360$

PKM Literasi Penguatan 3-M (Memakai Masker, Mencuci Tangan, dan Menjaga Jarak) Melalui Metode Storytelling di Pondok Pesantren Nurul Jadid Probolinggo

Mohammad Sofyan Adi, Dina Nur Faizah, Kamelia Yulia Novita, Robiatul Adawiyah, Ulfatul Nimatillah, Nuriah Waizul Romdani

361-368

PKM Pendampingan Pembelajaran Materi Bangun Datar dengan Billingual LED Running Text di Madrasah Ibtidaiyah (MI) Az-Zainiyah II Paiton Probolinggo

Nur Hamid, Muhammad Faiz Nailun Ni'am, Cahyu Guswita, Saiful Islam, Silviana Qomariyah, Siti Fatimah, Siti Khoifah

369-383

PKM Pendampingan Literasi Business Plan untuk Meningkatkan Pengetahuan dan Keterampilan Berwirausaha Santri Pesantren Nurul Jadid Mohammad Syaiful Suib, Yoviana Fitri, Lailatus Sa'adah, Nuril Fitriani, Widad Ulfatul Mawaddah Hadi, Siti Aisyah, Isna Shifah 
384-403

PKM Penanaman Karakter Berbasis Keagamaan bagi Warga Binaan Rumah Tahanan Kelas II. B Kraksaan Probolinggo Jawa Timur

Ahmad Fawaid, Muhammad Zaimul Millah, Achmad Naufal Baidawi, Siti Arofah, Nur Khofifah, Elmiyatus Soliha, Syukron Jazila, Rif'ah Hasanah, M Zainuddin

404-416

PKM Pendampingan Menghafal Al-Quran dengan Metode An-Nur pada Siswa Kelas X IPA Tahfidz Madrasah Aliyah Nurul Jadid Paiton Probolinggo

Abdurrahman, Indriani Putri Ayu Lestari, Lailia Mutmainnah, Hakimatus Sailah, Ika Fitri Anwar, Sofiya Mauliza, Nadya Afkarina

417-423

PKM Peningkatan Pendapatan pada Bidang Keputrian Wilayah Az-Zainiyah Pondok Pesantren Nurul Jadid melalui Strategi Pemasaran Berbasis Web

Anis Yusrotun Nadhiroh, Dina Wahyuni Suciati, Dzurrotun Nafila, Eva Nurmaliya, Nabila Maulidir Roziqina Fara 


\title{
PKM Deteksi Dini Kelainan Tumbuh Kembang dengan Skrining Denver /l dan Health Education di Taman Pendidikan Anak Shaleh Nurul Jadid Paiton Probolinggo
}

\author{
Zainal Munir ${ }^{1}$, Zainul Hasan²,
}

Siti Nur Kholishoh' ${ }^{3}$, Melinia Akhirul Fitri ${ }^{4}$

Universitas Nurul Jadid 1,2,3,4

\{zainalmunirnj@gmail.com ${ }^{1}$, zenn2205@gmail.com ${ }^{2}$, $\underline{\text { sitinurkhalishah8@gmail.com }}{ }^{3}$ meliniaaf2000@gmail.com $\left.^{4}\right\}$

Submission: 2021-06-12 Received: 2021-08-21 Published: 2021-08-31

\section{Keywords:}

Toodler,

Denver,

Growth and

Development

\begin{abstract}
Humans will be always continue to experience changes throughout their lives. Starting from the womb, being born then becoming an adult and old, in the process humans continue to experience changes in physical, movement, thought, emotional, and social aspects. The pattern of change is weak at first, then increases, reaches to a peak, then decreases. Improvement occurs in the process of growth, development and maturity. Institutions need to ensure that the stages of growth and development run according to the age of the child. Examination of growth and development is usually done by the teacher. Objectives: Early detection of child development and providing information on the importance of early stimulation, early examination and early intervention. The method of activity carried out is measuring Growth and Development using the Denver Developmental Screening Test II form, the sectors of the examination include (Personal SocialAdaptive Fine Motor-Language-Gross Motoric). The interpretations for the entire test were categorized into 3, namely, "Normal", "Suspected", and "Cannot be tested" in the families of children in TP Anak Shaleh Nurul Jadid. Results: This activity was accompanied by 7 parents, 5 teachers and 15 early childhood students participated in the activity actively, the results of the interpretation of the activity obtained that 12 early childhood students were declared normal and 3 early childhood students were declared unable to be tested because there were several factors in the results of the examination. As well as recommendations to parents for re-examination. Conclusion: so it needs special attention for parents and teachers to understand the growth and development of their children and how to stimulate children's growth and development.
\end{abstract}

\begin{tabular}{ll} 
Katakunci: & Abstrak. Manusia akan terus mengalami perubahan sepanjang \\
Balita; & hidupnya. Dimulai dari dalam kandungan, lahir kemudian menjadi \\
Denver; & dewasa dan tua, pada proses tersebut manusia terus mengalami \\
Tumbuh & perubahan dalam aspek fisik, gerak, pikir, emosi, dan sosial. Pola \\
Kembang; & perubahan tersebut mula-mula bersifat lemah, lalu meningkat, \\
TP Anak Shaleh & mencapai puncak, kemudian akan menurun. Peningkatan terjadi \\
\hline
\end{tabular}




\begin{abstract}
dalam proses pertumbuhan, perkembangan dan kematangan. Lembaga perlu untuk memastikan tahapan tumbuh-kembang berjalan sesuai dengan usia anak. Pemeriksaan tumbuh-kembang biasa dilakukan oleh guru. Tujuan PKM ini adalah mendeteksi dini perkembangan anak dan memberikan informasi pentingnya stimulasi dini, pemeriksaan dini dan intervensi dini. Metode kegiatan yang dilakukan adalah pengukuran Tumbuh Kembang dengan menggunakan formulir Denver Developmental Screening Test II, sektor dari pemeriksaan diantaranya (Personal Sosial-Adaptif Motorik HalusBahasa-Motorik Kasar). interpretasi untuk keseluruhan tes dikategorikan menjadi 3 yaitu, "Normal", "Suspek", dan "Tak dapat diuji" pada keluarga anak di TP Anak Shaleh Nurul Jadid. Kegiatan ini didampingi oleh 7 orangtua, 5 ustadzah dan dikuti sebanyak 15 siswa TP Anak Shaleh yang mengikuti kegiatan dengan aktif. Hasil dari kegiatan ini didapatkan 12 siswa TP Anak Shaleh dinyatakan normal dan 3 siswa TP Anak Shaleh dinyatakan tidak dapat diuji dikarenakan ada beberapa faktor didalam hasil pemeriksaan serta rekomendasi pada orangtua untuk dilakukan pemeriksaan ulang. Kondisi itu perlu menjadi perhatian khusus untuk orangtua dan ustadzah bisa memahami pertumbuhan dan perkembangan anaknya dan cara menstimulus tumbuh-kembang anak.
\end{abstract}

\title{
1 Pendahuluan
}

TP Anak Shaleh Nurul Jadid Karanganyar Paiton Probolinggo merupakan pendidikan pra sekolah yang dimiliki oleh Pesantren Nurul Jadid. Lembaga dasar yang akan dilalui oleh anak dalam menempuh pendidikan selanjutnya. Maka, lembaga perlu untuk memastikan tahapan tumbuh-kembang berjalan sesuai dengan usia anak. Pemeriksaan tumbuhkembang biasa dilakukan oleh guru. Tapi hanya sebatas pengukuran tinggi badan dan tinggi badan. Jadi secara teori dalam keperawatan anak masih belum mencerminkan tahapan pemeriksaan yang semestinya. Terlebih di tengan pandemic covid19 proses pembelajaran banyak dilakukan secara online. Sehingga selama hampir 1 tahun peserta didik tidak dilakukan pemeriksaan tumbuhkembang. Maka, alasan kami memilih program deteksi dini dan penyuluhan di TP Anak Shaleh Nurul Jadid adalah untuk memberikan gambaran umum tentang hasil pemeriksaan pertumbuhan dan perkembangan anak yang dilakukan. Pemaparan hasil pemeriksaan akan dilanjutkan dengan penyuluhan kepada orangtua dan guru untuk membantu meningkatkan pertumbuhan dan perkembangan berdasar setiap hasil interpretasi tiap anak. 
Manusia akan terus mengalami perubahan sepanjang hidupnya. Dimulai dari dalam kandungan, lahir kemudian menjadi dewasa dan tua, pada proses tersebut manusia terus mengalami perubahan dalam aspek fisik, gerak, pikir, emosi, dan sosial. Pola perubahan tersebut mula-mula bersifat lemah, lalu meningkat, mencapai puncak, kemudian akan menurun. Peningkatan terjadi dalam proses pertumbuhan, perkembangan dan kematangan (Martina \& Siregar, 2020; Rio Prasetyo, 2016).

Pada tahapan-tahapan perkembangan tersebut, masa anak-anak merupakan 2 masa dimana terjadi perkembangan yang sangat menakjubkan dan terbaik sepanjang hidup manusia. Masa anak-anak juga sering disebut dengan masa keemasan (golden age). Masa anak-anak ini terjadi pada saat anak beumur 0-8 tahun. Ahli perkembangan anak mengatakan bahwa anak usia dini adalah anak sejak dilahirkan sampai berusia 0-8 tahun yang terbagi dalam beberapa tahapan berdasarkan usia yaitu infancy (0-1 tahun), toddler (1-3 tahun), preschool ( 3-4 tahun), early primary years ( 5-6 tahun) dan later primary years (7-8 tahun) (Soetjiningsing, 2015).

Stimulasi perkembangan menjadi hal yang sangat penting bagi perkembangan anak. Anak yang mendapatkan stimulus yang terarah dan teratur akan lebih cepat berkembang dibandingkan anak yang kurang mendapat stimulus. Upaya stimulus menjadi peran orangtua dalam meningkatkan stimulus pada anak. Upaya stimulus bisa diberikan dengan permainan lego. Sehingga perkembangan motorik halus dan motoric kasar bisa sesuai dengan tahapan tumbuh kembangnya (Andarwati et al., 2019; Ivantoni \& Muhimmah, 2015; Munir, 2015; Munir et al., 2019; Wariantini Hadi et al., 2019).

Salah satu komponen paling penting dalam penilaian kesehatan komplet adalah pengkajian fungsi perkembangan. Prosedur skrining dirancang untuk mengidentifikasi secara cepat dan dapat diandalkan anak yang tingkat perkembangannya di bawah normal untuk usia mereka dan memerlukan penyelidikan lebih lanjut. Prosedur tersebut juga merupakan suatu alat pencatatan pengukuran objektif fungsi perkembangan saat ini sebagai rujukan di masa yang akan datang. Bila pemeriksaan dilakukan dengan bantuan aplikasi akan memudahkan dan mempercepat pendiagnosaan sebuah kegagalan tumbuh kembang. Sebagaimana penelitian yang dilakukan oleh (Syaroni \& Munir, 2020) tentang stunting akan lebih 
mempercepat penambilan keputusan. Hal itu akan memutuskan hambatan yang dihadapi oleh guru PAUD dalam pengambilan data pada anak (Dewi \& Erawati, 2014).

Perkembangan adalah bertambahnya kemampuan dalam struktur dan fungsi tubuh yang lebih kompleks dalam pola yang teratur dan dapat diramalkan, sebagai hasil dari proses diferensiasi dari sel-sel tubuh, jaringan tubuh, oragan-organ dan sistem organ yang berkembang sedemikian rupa sehingga masing-masing dapat memenuhi fungsinya. Termasuk juga perkembangan emosi, intelektual, dan tingkah laku sebagai hasil interaksi dengan lingkunngannya (Soetjiningsing, 2015).

Uji skrining perkembangan yang digunakan paling luas untuk anak kecil adalah Denver II. Denver II merupakan tes skrining untuk anak berumur antara 0-6 tahun. Denver II memiliki 125 tugas dan dikelompokan menjadi 4 sektor yaitu personal sosial, gerakan motorik halus, gerakan motorik kasar dan bahasa. Setiap tugas digambarkan dalam bentuk kotak persegi panjang horisontal yang berurutan menurut umur, dalam lembar Denver II (Khasan et al., 2014).

Walaupun uji skrining merupakan metode yang efektif dalam menerapkan pengetahuan tentang laju perkembangan yang diharapkan dari anak untuk segmen populasi yang luas, uji tersebut hanya akan berhasil jika diberikan oleh individu yang berpengalaman dalam memberikannya. Karena banyak uji skrining merupakan alat yang dibuat untuk digunakan oleh tenaga terlatih bantuan, terdapat risiko yang terkandung dalam skrining jika individu-individu tersebut tidak terlatih atau tidak diawasi secara tepat.

Perawat yang memberikan skrining perkembangan harus diawasi oleh tenaga terlatih, perlu mengkaji gambaran keseluruhan anak dan tidak hanya mengandalkan prosedur skrining. Perkembangan seperti halnya pertumbuhan dan kesehatan, adalah suatu proses dinamis. Tes seperti Denver II sebaiknya digunakan sebagai bagian dari survailens perkembangan, suatu pendekatan perawatan kesehatan primer yang komperhensif dan terus-menerus yang melibatkan orang tua sebagai mitra paraprofesional. Evaluasi kesehatan total anak adalah hasil evaluasi data riwayat kesehatan dan keluarga yang komperhensif, pemeriksaan fisik, dan skrining perkembangan. 
Kegiatan skrining ini dilakukan sebagai salah satu bentuk pengabdian kepada masyarakat Dosen Universitas Nurul Jadid dan Mahasiswa Sarjana Keperawatan Fakultas Kesehatan UNUJA yang dilakukan di TP Anak Shaleh Nurul Jadid selama dua hari.

Menelaah dari situasi dan realita yang terjadi di masyarakat dengan obyek anak-anak sebagai sasaran pemeriksaan skrining denver disinibahwasanya ada bberapa fakta yang menjadi kekhawatiran masyarakat karena adanya keterlamabatan anak itu tumbuh dan berkembang dalam batas usianya. Maka dari itu pemeriksaan ini dilakukan dan diharapkan dapat membantu segala problema serta kekhawatiran keluarga terhadap tumbuh kembang pada anaknya dan tetap bisa mengontrol hal-hal apa saja yang perlu dan tidak boleh di ajarkan untuk terus memantau tumbuh kembang pada anaknya.

\section{Metode}

\section{Strategi Pelaksanaan}

Strategi yang ditempuh dalam pelaksanaan skrining Denver II ini, diantaranya:

1. Mencari lokasi yang dapat dijadikan tempat skrining (TP Anak Shaleh Nurul Jadid)

2. Kerja sama pihak kampus dengan pihak TP Anak Shaleh Nurul Jadid

3. Mendiskusikan waktu dan sistem pelaksanaan

4. Mempersiapkan tim dan perlengkapan yang digunakan

5. Melakukan kunjungan dan melakukan skrining dan helath education dengan mengikuti Protokol Kesehatan

6. Menganalisa dan melaporkan hasil kunjungan 


\section{Persiapan}

Persipan yang dilakukan sebelum pelaksanaan skrining Denver II di TP Anak Shaleh Nurul Jadid yaitu:

1. Persiapan perlengkapan alat dan bahan yang akan digunakan untuk skrining seperti alat denver, lembar pengkajian Denver II dan tim untuk skrining dan persiapan penyuluhan berupa materi penyuluhan dan pemateri

2. Persiapan anak dan keluarga/orang tua di TP Anak Shaleh Nurul Jadid

3. Persiapan fasilitator selama pelaksanaan skrining

4. Persiapan kuisioner sebagai bahan evaluasi

\section{Penilaian Keseluruhan Tes}

Hasil interpretasi untuk keseluruhan tes dikategorikan menjadi 3 yaitu, "Normal", "Suspek", dan "Tak dapat diuji". Penjelasan mengenai ketiga kategori tersebut adalah sebagai berikut.

1. Normal. Interpretasi NORMAL diberikan jika tidak ada skor "Terlambat" (0 T) dan/atau maksimal 1 "Peringatan" (1 P). Jika hasil ini didapat, dilakukan pemeriksaan ulang pada kunjungan berikutnya.

2. Suspek. Interpretasi SUSPEK diberikan jika terdapat satu atau lebih skor "Terlambat" (1 T) dan/atau dua atau lebih "Peringatan" (2 P). Ingat dalam hal ini, $T$ dan $P$ harus disebabkan oleh kegagalan $(G)$, bukan oleh penolakan (M). Jika hasil ini didapat, lakukan uji ulang dalam 1-2 minggu mendatang untuk menghilangkan faktor-faktor sesaat, seperti rasa takut, sakit atau kelelahan.

3. Tidak dapat diuji. Interpretasi TIDAK DAPAT DIUJ diberikan jika terdapat satu atau lebih skor "Terlambat" (1 T) dan/atau dua atau lebih "Peringatan" (2 P). Ingat, dalam hal ini, T dan P harus disebabkan oleh penolakan (M), bukan oleh kegagalan (G). Jika hasil ini didapat, lakukan uji ulang dalam 1-2 minggu mendatang. 
Catatan: jika hasil tes berulang kali menunjukkan SUSPEK atau TIDAK DAPAT DIUJI. Anak perlu menjalani sesi konsultasi dengan seorang ahli, guna menentukan keadaan klinis anak berdasarkan:

a. Profil hasil tes (item yang mendapat nilai "PERINGATAN" atau "TERLAMBAT");

b. Jumlah "PERINGATAN" dan "TERLAMBAT";

c. Tingkat perkembangan sebelumnya;

d. Perhatikan klinis lainnya (riwayat klinis, pemeriksaan kesehatan, dll.); dan

e. Sumber rujukan yang tersedia.

Dalam prakteknya disini kami berkolaborasi antara beberapa mahasiswa Keperawatan beserta dosen jurusan Keperawatan Anak untuk bisa melakukan dan mensukseskan adanya kegiatan pengabdian masyarakat yaitu Pemeriksaan skrining Denver. Dimana subyek kami disini adalah anakanak TP Anak Shaleh Nurul Jadid, dan dalam prosesnya kami meminta keiikutsertaan guru serta orang tua ataupun pengasuh anak agar bisa mengetahui setiap tata cara melakukan pemeriksaan skrining denver dan ini bisa jadi ilmu baru untuk mempraktekkannya kepada anak didiknya di masa yang akan datang dan terus bisa memantau tumbuh kembang mereka. Dengan seperti itu kami harapkan tujuan kami bisa tercapai dalam pemeriksaan skrining dengan hasil normal secara keseluruhan. Karena dalam pemeriksaan yang dilakukan anak susah menunjukkan kebisaan yang sering dilakukan apabila tidak didampingi keluarga atau orang terdekatnya, hal ini dapat menyebabkan hasil akan berbeda dengan fakta keseharian anak. Maka dari itu kami melibatkan orang tua atau pengasuh masingmasing anak sebagai sampel kedua apabila anak banyak penolakan dalam beberapa sektor dalam pemeriksaan skrining denver seperti sektor personal sosial, sektor motorik halus, sektor bahasa, sektor motorik kasar. Sehingga hasil yang didapatkan bisa sesuai dengan fakta yang ada dan anak itu bisa dan mampu tumbuh serta berkembang sesuai batas usianya.

Diagram Metode: 


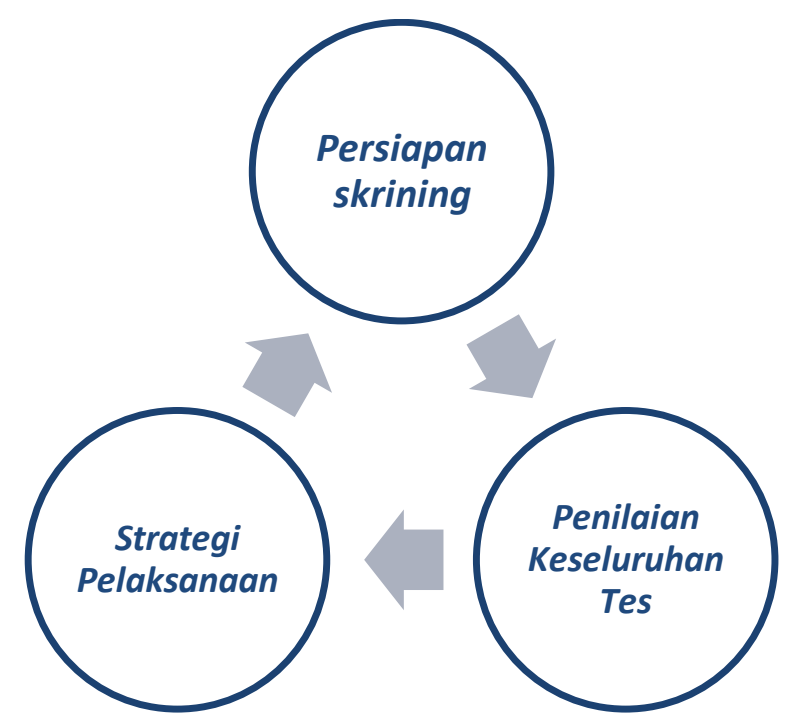

Gambar 1. Diagram Metode

\section{Hasil dan Pembahasan}

Kegiatan penelitian ini dilakukan oleh Mahasiswa Sarjana Keperawatan Fakultas Kesehatan UNUJA, yang diawasi oleh dosen pembimbing yang terlatih dalam pengkajian Denver II. Tahap tumbuh kembangan anak tidak luput dari peran serta orang tua yang hakikatnya berkewajiban memberikan segala kebutuhan yang terbaik bagi perkembangan fisik maupun psikis anak. Nutrisi makanan dan lingkungan juga mempunyai peranan penting bagi tumbuh kembang anak, selain itu dibutuhkan instansi pendidikan Pra Sekolah yang tepat untuk membantu tugas orang tua mengontrol dan memperhatikan perkembangan anak. Kegiatan ini dimulai dengan pengkajian Denver II pada anak kemudian dianalisa hasil pengkajian dan selanjutnya melakukan penyuluhan atau pendidikan kesehatan pada orang tua terkait dengan perkembangan dan gizi anak sesuai dengan tahap perkembangan. Adapun proses pelaksanaan kegiatan yang dilakukan pada masing-masing anak oleh tiap mahasiswa. Pengkajian dilakukan dengan melibatkan keluarga terdekat anak untuk mengkaji beberapa aspek perkembangan anak. Setelah melakukan pengkajian dan dianalisa, selanjutnya mahasiswa memberikan reward, motivasi dan edukasi kesehatan kepada keluarga untuk mempertahankan dan meningkatkan kesehatan anak. Intervensi penyuluhan kesehatan pada keluarga juga diberikan setalah dilakukannya skrining denver dan pemeriksaan 
antropometri. Materi yang disampaikan terkait dengan tahap perkembangan untuk anak usia pre school dan gizi seimbang. Penyuluhan kesehatan dilakukan kurang lebih 90 menit. Partisipasi peserta penyuluhan banyak yang mengajukan pertanyaan tentang menu dan pola gizi yang baik.

Anak akan mengalami suatu periode yang dinamakan sebagai masa keemasan anak saat usia dini dimana saat itu anak akan sangat peka dan sensitif terhadap berbagai rangsangan dan pengaruh dari luar. Laju perkembangan dan pertumbuhan anak mempengaruhi masa keemasan dari masing-masing anak itu sendiri. Saat masa keemasan, anak akan mengalami tingkat perkembangan yang sangat drastis dimulai dari perkembangan berpikir, perkembangan emosi, perkembangan motorik, perkembangan fisik dan perkembangan sosial.

Berdasarkan hasil skining, lebih dari 90\% anak di TP Anak Shaleh Nurul Jadid termasuk dalam kategori normal baik pertumbuhan (antropometri) maupun perkembangan (denver II). Tingkat pencapaian perkembangan anak usia dini adalah deskripisi tentang perkembangan yang dicapai merupakan integrasi aspek fisik-motorik, kognitif, sosial-emosi, moral agama dan kondisi kesehatan serta gizi anak.

Perkembngan anak berlangsung secara kontinum, tingkat perkembangan yang dicapai pada suatu tahap diharapkan meningkat secara kuantitatif maupun kualitatif pada tahap selanjutnya. Terdapat perbedaan individual dalam perkembangan, karena terdapat pengaruh beberapa faktor internal maupun eksternal sehingga setiap anak memiliki karakter yang unik meskipun tetap berdasarkan atas pola perkmbangan umum. Untuk mencapai tingkat perkembangan yang optimal dibutuhkan keterlibatan orang dewasa untuk memberikan rangsangan atau stimulasi. Diperlukan rangsangan yang bersifatholistik yang meliputi pendidikan, psikososial, kesehatan, dan gizi yang diberikan secara konsisten dan berulang.

\section{Kesimpulan}

Dalam dunia pendidikan anak usia dini (PAUD) perkembangan anak merupakan hal yang harus diperhatikan karena perkembangan anak secara lanjut akan menentukan proses pembelajaran anak tersebut di jenjang selajutnya. Perkembangan berkenaan dengan keseluruhan kepribadian 
anak, karena kepribadian membentuk satu kesatuan yang terintegrasi. Secara umum dapat dibedakan beberapa aspek utama kepribadian anak, yaitu aspek intelektual, fisikmotorik, sosial, emosional, dan bahasa. Perkembangan dari setiap aspek tidak selalu sejajar, perkembangan sesuatu aspek mungkin juga mengikuti aspek lainnya.

\section{Pengakuan}

Kami selaku pembimbing dan mahasiswa KKN S1 Keperawatan Fakultas Kesehatan Universitas Nurul Jadid mengucapkan terimaksih atas partisipasi dari pihak TP Anak Shaleh Nurul Jadid beserta keluarga karena telah banyak membantu kami dalam proses kegiatan Pemeriksaan Screening Denver II.

\section{Referensi}

Andarwati, S. R., Munir, Z., \& Siam, W. N. (2019). PERMAINAN LEGO (PARALLEL PLAY) TERHADAP PERKEMBANGAN MOTORIK HALUS PADA ANAK USIA 3-6 TAHUN Siska. Journal of Chemical Information and Modeling, 53(9), 1689-1699.

Dewi, R. C., \& Erawati, M. (2014). Pengalaman Pengajar PAUD Dalam Pelaksanaan Skrining Denver II Pada Anak Usia Pra Sekolah. Jurnal Keperawatan Anak, 2(2), 102-107.

Ivantoni, R., \& Muhimmah, I. (2015). Aplikasi Penentuan Tingkat Tumbuh Kembang Anak Menggunakan Tes Denver II. Seminar Nasional Informatika Medis (SNIMed) VI, VI, 124-132.

Khalid, A., \& Wahyudi, A. (1985). Kisah Walisongo Para Penyebar Agama Islam di Tanah Jawa. Karya IImu.

Khasan, U., Siska, G., \& Oktiawati, A. (2014). Perbedaan Hasil Pengukuran Perkembangan Balita Menggunakan Denver Developmental Screening Test II (Denver II) dan Kuesioner Pra Skrining Perkembangan (KPSP). Jurnal Keperawatan Anak, 2(1), 44-51.

Martina, S. E., \& Siregar, R. (2020). Deteksi Dini Stunting Dalam Upaya Pencegahan Stunting Pada Balita Di Desa Durin Tonggal, Pancur Batu, Sumatera Utara. Jurnal Abdimas Mutiara, 1(1), 42-47. 
Munir, Z. (2015). keperawatan infeksi pada anak. In Setiyo (Ed.), Pediatrik nursing (1st ed., p. 300). ECG.

Munir, Z., Yulisyowati, \& Virana, H. (2019). Hubungan Pola Asuh Orang Tua dalam Menstimulasi Perkembangan Motorik Kasar dan Halus Usia Pra Sekolah. Jurnal Keperawatan Profesional, 7(1), 1-17.

Nur, I. M. (2001). Differing Responses to an Ahmadi Translation and Exegesis: The Holy Qur'an in Egypt and Indonesia.

Rio Prasetyo. (2016). Pendidikan jasmani kesehatan dan rekreasi fakultas ilmu keolahragaan universitas negeri semarang 2013. In Hubungan Antara Tingkat Kecerdasan Emosional (Eq) Dan Konsentrasi Terhadap Kemampuan Juggling Pada. UNIVERSITAS NEGERI SEMARANG.

Soetjiningsing. (2015). Tumbang anak (G. Ranuh (ed.); 1st ed.). EGC.

Syaroni, W., \& Munir, Z. (2020). Pemanfaatan aplikasi android dalam mendiagnosa dan memonitoring kasus stunting lebih dini. Jurnal Teknik Elektro Dan Komputer, 9(3), 189-196.

Wariantini Hadi, Y. M., Munir, Z., \& Siam, W. N. (2019). Efektifitas Penerapan Metode Family-Centered Care terhadap Pasien Anak dengan Stress Hospitalisasi. Citra Delima: Jurnal IImiah STIKES Citra Delima Bangka Belitung, 3(2), 112-116. https://doi.org/10.33862/citradelima.v3i2.69

Zulkifli. (1994). Sufism in Java: The Role of the Pesantren in the Maintenance of Sufism in Java. Master Thesis. Australian National University. 


\section{GUYUB}

\section{Journal of Community Engagement}

P-ISSN: 2723-1232

E-ISSN: 2723-1224

GUYUB: Journal of Community Engagement is is a multidisciplinary journal which aims to disseminate the conceptual thoughts and research results in the area of community service. This journal focuses on the main problems of the community engagement areas, such as (1) training, marketing, appropriate technology, design; (2) student community services; (3) community empowerment, social access; (4) education for sustainable development, etc.

GUYUB: Journal of Community Engagement is published three times a year (April, August, December) by Lembaga Penerbitan, Penelitian, dan Pengabdian kepada Masyarakat (LP3M) Universitas Nurul Jadid, Paiton, Probolinggo, Jawa Timur, Indonesia.

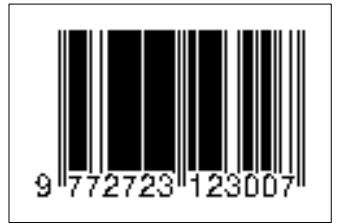

Editorial Office:

GUYUB: Journal of Community Engagement

Lembaga Penerbitan, Penelitian, dan Pengabdian kepada Masyarakat

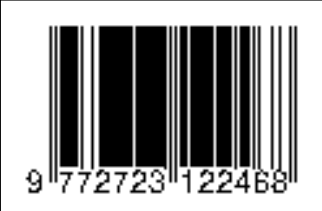

(LP3M) Universitas Nurul Jadid, Probolinggo, Jawa Timur, Indonesia 67291.

Phone: 088830 77077, Hp: 082318007953

Email: jurnal.guyub@gmail.com

Website: https://ejournal.unuja.ac.id/index.php/guyub/index 